\title{
The Influence of Mongolian Students' Emotional Factors on Language Acquisition
}

\author{
Kun Li \\ School of Foreign Languages \\ Inner Mongolia University for the Nationalities \\ Tongliao, China \\ e-mail: likunfsu@163.com
}

\begin{abstract}
The influence of Mongolian students' emotional factors on language acquisition is analyzed and discussed in detail in this paper. Classroom observation and interviews are used to get support in the research. The research concludes that the cultivation of students' positive emotional factors can bring desirable effects on their language acquisition. So teachers' tasks include not only teaching language itself, but also creating students' active emotional factors at the same time in order to make a successful language-learning environment.
\end{abstract}

Keywords—emotional factors; language; Mongolian; effect

\section{INTRODUCTION}

Throughout the teaching process, cognitive activities and emotional activities are intertwined. In language teaching and learning activities, teachers and students are not only teaching, learning and developing students' intelligence; but also communicating their emotions and cooperating with each other in language activities.

Emotional factors refer to people's attitudes to experience; that is to say, people can reflect their satisfaction on things. Previous studies show that if the emotional factor is low or destroyed, people's creativity and development cannot be achieved. Positive emotional factors can successfully improve learning outcomes.

Teachers' emotional factors directly affect their students' emotional factors in the classroom, which in turn affect students' learning outcomes. Students show different emotional factors to all learning activities and courses, and even teachers. Those who show positive emotional factors are willing to exchange their ideas with teachers in the classroom and are always active in class; those who show negative emotional factors are not likely to collaborate in the classroom, and therefore cannot achieve satisfactory learning results. Creating a harmonious atmosphere for students in terms of learning is essential, and it must rely on the expression of good teachers and students' emotional factors.

The purpose of this study is to highlight that, currently, in colleges and universities, especially in the education for minority students, for example, in Inner Mongolia, students'

This work is sponsored by Center for Teaching and Learning Development in Inner Mongolia University for the Nationalities, No.MDYB2013005 emotional factors have important influences on language acquisition. Teachers' and students' emotional factors are crucial to creating a harmonious classroom environment for language learning and acquisition, arousing people's attention on the quality of teachers.

The purpose of education is to promote the overall development of students. This study is designed to investigate the emotional factors of Mongolian students in learning the language, especially when they are expressing themselves in English. The study on favorable and unfavorable influences of emotional factors on students' language acquisition can help students change their negative emotional factors, remove their anxiety and fear, and thus improve teaching methods, and the quality of teachers. In this way, Mongolian students' language learning can come into a new stage. Teachers should eliminate the psychological barriers of language learning for students in school, let students successfully finish their language learning and acquisition, and lay a good foundation for students' future employment.

Teachers' and students' emotional factors are both important in creating a harmonious language-learning atmosphere. A kind and active teacher can take students into a warm learning and acquisition atmosphere, and make language learning and acquisition natural and welcome. At the same time, positive emotional factors from students can guarantee that students learn the language without fear and anxiety. With a happy mood, people can do things quickly and successfully.

\section{THE IMPORTANCE OF EMOTIONAL FACTORS IN LANGUAGE ACQUISITION}

\section{A. Emotional factors in people's mind}

For centuries, emotional factors have attracted people's attention. In the west, harmonious education originates in ancient Greece, which emphasizes the development of education in the common physical and mental state. People believe that emotional factors can enhance students' memories. Memory is one of the most important factors in language acquisition. For example, learning vocabulary, phrases, grammar and other language points all require good memory. Positive emotional factors can make memory 
activities become active and relaxing, and thus can strengthen the memory effect. Based on some findings of psychology, the most important role of emotional factors is to organize and strengthen the human cognitive activities. Effective emotional factors can ensure effective cognitive activities and affect cognitive effects.

Of all the classroom emotional factors, anxiety can be considered as the most distinctive one. It is known as a psychology concept first, and is a kind of emotion that is common in people's everyday life. When people face a problem that is hard for them to solve, or when they think they may do something wrong, they will produce this kind of emotion - anxiety. In all kinds of classrooms anxiety may exist, but in a language classroom where a different language is spoken, anxiety may be more severe.

Because of its unique influence in a classroom, anxiety is one of the most important emotional factors in language learning and acquisition. Anxiety, fear and tension will consume the energy and attention of learners, which will greatly affect their learning. Anxiety is a student's fear of making mistakes in language learning, and it will greatly affect student-learning outcomes, and even lead students to abandon language learning along the way.

\section{B. Studies on Emotional Factors}

In recent years, both Chinese and foreign researchers and teachers have done considerable research on emotional factors. They find the importance of emotional factors in language learning and acquisition. Emotional factors of teachers and students are both studied in order to create a better language learning and acquisition environment for students. Tests, questionnaires, interviews and classroom observations are often used by researchers to get the results.

In English Curriculum Standard, detailed explanation about developing language learners' emotional factors is made to form a standard in language learning and teaching. The standard illustrates that learners' emotional factors are crucial aspects of language learning and acquisition efficiency and success. Teachers should consider these factors in class to generate a desirable classroom outcome. Positive emotional factors are the main task for teachers in language education. Teachers should consider all they can do to ensure that their students have positive emotional factors in class; without the hindrance of negative factors on the development of language abilities.

Researchers in and out of China have done many studies to emphasize the importance of emotional factors in language learning and acquisition. Most of the studies state the use of positive emotional factors in the classroom to ensure the successful classroom effect. These studies list some rules or principles for successful classroom management. They give suggestions and requirements to teachers to guide them to set up a harmonious classroom atmosphere. Psychology and theory aspects are also discussed in these studies.

Ethnic minority students are a special group of language learners. They learn three kinds of languages at least: their own minority language, Chinese and a foreign language. So their language learning and acquisition task is heavier than others. The studies on minority students' language learning have been done by teachers and researchers, especially in minority areas, for example, Inner Mongolia. Liu (2013) states it is necessary to activate students' emotional factors based on the study of Mongolian students' language learning and acquisition.

\section{The CURRENT Situation OF MONGOLIAN}

\section{STUDENTS' LANGUAGE LEARNING AND ACQUISITION}

This study analyzes the current situation of English learning and acquisition in minority concentrated regions, especially in universities that enroll Mongolian English majors. In these kind of universities, a larger proportion of students are Mongolian. Foreign language learning is an important part of the activities involved in Mongolian students' studying experiences. Foreign language learning directly affects the direction of students' employment. Mongolian students' foreign language learning and acquisition is a particularly important part of foreign language teaching.

Most Mongolian students have limited time and opportunity to come into direct contact with a foreign language before they come to university. This situation makes language learning difficult in university. At the same time, students' emotional factors also greatly affect the effectiveness of language learning and acquisition. Currently at the university, Mongolian students' emotional factors have a major impact on language acquisition.

In Inner Mongolia, there are some Mongolian students who major in English. Before they begin university, their English level is relatively low. Their scores of entering the university are not as high as those in other classes. These students' mother tongue is Mongolian. Usually when they start their education, they begin to learn Chinese formally. When they come into junior high school, they begin to learn English. But the situation is that most of the teaching is done in Chinese. Because of their limited Chinese level, they have difficulty in understanding another language - English. Their scores upon entering university are not high and that is to say, they have much more difficulty in learning English.

In university, the majority of courses are taught in English. In some cases, when teachers want to explain some difficult points, they use Chinese to help them. As students whose native language is not Chinese, their understanding of the Chinese explanation will be affected. Some teachers' explanations will not be understood effectively and quickly. Nowadays, Mongolian English majors' learning and acquisition receive substantial attention from teachers and researchers. People want to find proper ways to improve the learning efficiency of Mongolian students. And this influences much of the development of the region.

As in some other universities, most English majors are female. So the classroom atmosphere is relatively quiet. This may influence students' active involvement in language acquisition; and influences the discussion on how to engage 
students to be enthusiastic about their learning. In recent year, this has become a hot topic.

\section{The Methods AND RESUlts OF THIS StUdy}

This study mainly focuses on the influence of Mongolian students' emotional factors on their language acquisition. The factors that influence students' English acquisition are analyzed in detail. Through classroom observation and interviews the study tries to find out the proper methods to improve Mongolian students' language acquisition.

\section{A. The Methods Used in the Study}

This study is conducted in a university for many nationalities. In the university, there are classes for Mongolian English majors.

\section{1) The subject}

Mongolian students are the subjects of the study, especially Mongolian English majors. Altogether 85 students are involved in the study. They are all English majors in the School of Foreign Languages. Most of them don't have a desirable English score when they enter university. Their mother tongue is Mongolian. When they begin their school experience, they start to learn Chinese. Until now, their Chinese is not that perfect. When they enter university, they major in English and start to learn another language. When they are in grade two, they will start to learn another foreign language as a second foreign language for English majors. This foreign language may be Japanese or French, or something else.

Most of the subjects are girls. So the classroom atmosphere is quiet most of the time.

\section{2) The study method}

In the study, classroom observation and interviews with teachers and students are used.

The subjects of the study belong to four classes of different grades. Four classroom observations are done by researchers, with the aim to finding out teachers and students' emotional factors shown in the classroom.

Besides classroom observation, teachers and students are interviewed separately to find out their views about emotional factors in learning a foreign language.

Classroom observation is a direct way to know the learning and teaching realities in class. In this study, researchers go into the classrooms to record things that happen in the classroom, teachers' explanation and organization of the class, and most importantly, students' emotional factors. Positive and negative emotional factors are both recorded to analyze the outcome of these emotions.

Interview is used both for students and teachers. Through the interview, researchers want to know the position of emotional factors in teachers and students' hearts.

\section{B. The Results of the Study}

During the classroom observation, it was found that emotional factors greatly influence the classroom atmosphere. In all four of these classes, most of the students are girls, with an average of one to three boys in each class. Usually the classroom atmosphere is quiet, so teachers are depended upon to motivate students to take part in the activities. If the teachers encouraged well, students would relax and gradually be willing to respond to teachers' requirement. But when they met difficult questions, most students would be silent, with their tension showing on their faces. Some of them were shy and would lower their heads when they thought they could not answer the questions. Sometimes, they looked at their teachers or classmates to see their emotions, and then mirrored the reactions they saw there.

When teachers create a fine classroom atmosphere, students are eager to answer questions and hands are frequently in the air. But most of them still feel shy when they don't answer the questions correctly. Teachers are required to change their methods from time to time in order to meet the students' need to conquer their negative emotional factors. Motivating these Mongolian students to take part in the learning activity with positive emotional factors is not an easy task because teachers must give their instructions in either English or Chinese; native Mongolian speakers sometimes cannot understand their teacher's intention correctly, or provide a correct response.

Interview results show different opinions about emotional factors from teachers and students. Some teachers say that emotional factors are very important for language teaching and learning. If students show positive emotional factors, they will actively take part in class activities, leading to a good classroom atmosphere. In this kind of atmosphere, teachers and students will communicate and cooperate with each other successfully. Students can learn their foreign language effectively. But some teachers have different opinions. They think in a classroom, the teachers' main task is to educate students, to impart knowledge with no responsibility of conquering students' emotions, no matter what these emotions may be. They believe that knowledge if the most important, and therefore admit that in their classroom, they seldom notice of importance of emotions when teaching their students.

In the interview with students, most believe emotional factors will influence their language output. If they learn the knowledge in a relaxing atmosphere, they will remember the words quickly, know the language points happily and be eager to accept the language. But if they have negative emotional factors in learning a language, they will feel upset, unwilling to respond to teachers, and nervous when they are going to answer questions. Most of them hope they can learn English in a relaxing environment. They want their teachers to treat them as friends. Only a few of them don't think it necessary to pay attention to emotional factors in the classroom.

\section{Suggestions for future language teaching and learning}

Through the classroom observation, the influence of emotional factors can be clearly shown. In situations where 
students have positive emotional factors, the outcome of learning is a happy one.

Teaching activities are the equal communication and cooperation between teachers and students. The emotional factors that influence language acquisition activities can be divided into two parts. The first part is students' individual elements, including fear, anxiety, oppression, low selfesteem and motivation. The second part is concerned with the emotional factors between learners and teachers, including classroom activities and cooperation.

Positive emotional factors can help build up a learners' active attitude towards language learning; the attitude towards learning is important because it influences the outcome greatly. If students have a positive attitude when they are learning their target language, they are willing and eager to accept the language input; on the contrary, if they have a negative attitude towards the target language, they are more likely to refuse or avoid every activity that is concerned with the that language.

Nowadays, researchers and teachers know that foreign language teaching and learning is a complex procedure. But in the process, objective laws exist. These laws are the things that teachers and students should try their best to find and follow. Foreign language learning is influenced by its subjective and objective factors. The harmonious development of teaching and learning, teaching contents and teaching methods, language factors and cultural factors, teaching requirement and the current need will influence the teaching and learning process and the learning outcomes directly. How to maximize the learning effect is a core element that teachers should notice. In recent years, peoples' attention is still focused largely on the research of cognition; the research on emotional factors should arouse people's attention at the same time. In fact, cognitive factors and emotional factors are closely related and they each play their important roles in language learning and acquisition activities.

Teachers should create a relaxing, free and happy learning atmosphere in order to arouse students' interest to learn. Students should be encouraged to take part in the learning activities, learn the necessary language and cultural knowledge, and be optimistic when receiving instruction, help and response from their teachers.

The methods for teachers to solve the problem of emotional factors include creating a harmonious learning environment for students. Harmoniousness not only fits for the development of the society and countries, but also fits for language acquisition activities in and out of the classroom.

Teaching materials and textbooks can be used creatively. In order to reduce students' anxiety and fear, teachers can choose the material constructively, and need not only pay attention to the amount of new language input. The material used in class should suit the students' learning level.

Communication between teachers and students should be emphasized. Teachers should know the approach of "individualized teaching" and design different learning content for students. In class, teachers should use proper and kind language. If teachers want their students to have positive and active emotional factors, they must show their emotions of being eager to teach to ensure the teaching process be accomplished successfully. The distance between teachers and students should be shortened by teachers' efforts.

As for teachers in minority regions, the use of students' mother tongue can sometimes be a big step to reduce students' anxiety. For example, in Inner Mongolia, if teachers can use Mongolian effectively in class when they have classes for Mongolian students, this can greatly help the students' understanding of the language. So in minority concentrated regions, teachers could be trained to learn some of that regions language. This can help to greatly improve their language teaching.

At the same time, humanism should be used in language teaching classrooms. Usually people only pay attention to students' intelligence development and ignore students' emotions. In humanism, educators advocate the full development of humans. Humanism can help teachers and students know self-esteem, self-reliance, and develop their potential to learn. By improving humanism in language teaching and learning, students' positive emotional factors can be enhanced and this would help language acquisition.

The aim of education is to fully develop students' abilities. This study makes a survey on the current acquisition conditions of Mongolian students, especially those who major in English. Positive emotional factors can influence an effective classroom atmosphere and the result of acquisition is successful. Teachers should study the negative emotional factors that appear in the classroom, and help students to overcome these, to conquer anxiety and at the same time improve the teaching methods and the teachers' qualities. If emotional factors are considered carefully and fully in the classroom, Mongolian students' language learning and acquisition can come into a new stage. Teachers should have the responsibility to help students learn language in a relaxing environment, help finish their study in university successfully and help them lay a solid foundation for their future study.

\section{CONCLUSION}

Emotional factors are actually complex matters and need to be solved in future teaching and learning environments. This cannot be done in a short period of time.

Emotional factors can hinder or accelerate the process of language acquisition. Teachers should pay much attention to students' emotional factors in class; this will ensure a good behavior from students, and ensure the cooperation between teachers and students. For students, teachers are their emotion educators. Students' emotional factors are greatly influenced by teachers' emotional factors. The emotional factors that students show in their language learning activities function effectively in their language acquisition. If students have positive emotional factors, they would like to accept the language input, but if they have negative emotional factors, they may refuse or avoid some relevant English learning activities. 
Different learning outcomes rely on different learning attitude, different motivation and different involvement from students. Motivation is the most important factor in English learning and acquisition. Active motivation can make a hard and boring task become a happy learning journey. Teachers should consider what they can do to make themselves an artist in language teaching, not merely a teaching media. Positive emotional factors are encouraged in the classroom to have a good influence on students' language acquisition.

\section{ACKNOWLEDGMENT}

I would like to give my thanks to the support of my university for the program. I should also say thank you to all the teachers and students who participated in the program and helped complete the classroom observation and interview. With the hard work of all the members in the program, the program can be finished successfully.

\section{REFERENCES}

[1] B. Han, and T. Yang, "The interpretation of emotional factors in English Curriculum Standard," Heilongjiang Researches on Higher Education, pp. 184-186, April 2009.

[2] Y. Liu, "The excitation of Mongolian students' English learning emotional factors in Comprehensive English learning," Journal of Inner Mongolia Normal University, vol. 26, pp. 125-126, September 2013.

[3] K. Li, "The improvement of foreign language teachers' affective variables in universities for ethnic minorities," English Language Teaching, vol. 5, pp. 70-75, December 2012.

[4] K. Li, "The Development and Utilization of School-based Curriculum for English Majors in Minority Concentrated Region," Proceeding of the International Conference on Education, Language, Art and Intercultural Communication, Vol 3, pp. 31-35, May 2014. 